\title{
The technique of project activity: A new approach in Russian preschool
}

\author{
Nikolay E. Veraksa ${ }^{\text {a*}}$, Aleksander N. Veraksa ${ }^{\mathrm{b}}$ \\ ${ }^{a}$ Moscow School of Social and Economic Sciences, Moscow, Russia \\ ${ }^{\mathrm{b}}$ Lomonosov Moscow State University, Moscow, Russia \\ *Corresponding author. E-mail: neveraksa@gmail.com
}

Project activity has a long history of implementation in education (Kilpatrick, 1918). This article describes the approach to project activity that became widespread in preschool education in Russia in the late 1990s. This approach is based on the culturalhistorical theory of Vygotsky (1978), Venger's (1988) understanding of intellectual giftedness, as well as an understanding of project activity proposed by Leontiev (2000).

At the heart of project activity lies children's exploration of the space of possibilities - that is, their search for action options that correspond to their personal motives and express their individuality. The main features of project activity are the problem situation to be presented to the child; the subjectivity of all its participants, including teachers; and its nature, which includes its social context.

Three main types of project activity are presented: research, creative, and normative; each has its own structure and value for children's development. Examples of their implementation in preschool settings are provided. The impact of project activity on all its participants in preschool - children, teachers, parents - is addressed.

The article shows the effectiveness of project activity for educational work with both intellectually gifted and normally developing children.

Keywords: project activity, giftedness, intellectual development, space of possibilities

The project-activity approach is widely used today not only in school education but also in work with small children (for example, Grzegorzewska \& KoniecznaBlicharz, 2011; Katz \& Chard, 2000; Kogan \& Pin, 2009). Although project activity has been a part of Russian school education since the 1990s, in preschool education it hasn't been recognized as a separate tool for organizing children's activity. 


\section{Historical background}

Project activity in Russia originated as a technique for working with intellectually gifted children and was developed by a team of researchers under the scientific guidance of L. Venger (1988). Venger based his research on the cultural-historical theory of L. Vygotsky. According to Vygotsky (1978), child development is a gradual entry into human culture through the mastery of cultural tools-that is, through the development of opportunities to explore the world and interact with it using culturally available methods. These culturally available tools are used not only to change the child's interaction with the world but also to change the child. Vygotsky's student A. N. Leontiev (2000) defined children's psychological development as a process of mastering various types of activity, such as play and productive activity (building, drawing, sculpting, and so forth); in other words, child development is conditioned by activity and occurs during it. Therefore, the products of children's activity are not deemed to seriously affect their development (for example, a drawing made by a child is a part of drawing activity, which exists outside the system of social interactions).

We began our work in 1998 in the city of Novouralsk with 2 preschools and 50 children who were 5 years of age ( 27 girls and 23 boys, $M=62$ months). The city was a scientific center with a large population of highly skilled specialists. The proportion of children with a high level of cognitive development in the city's kindergartens was higher than the proportion in the rest of the country's preschools.

Our research showed the existence of two opposing approaches in educational work with preschool children (Veraksa \& Bulicheva, 2003). In the first one, children are given maximal freedom of action; in the other their activity is rigidly determined by the grown-ups. Both approaches have, in our opinion, serious shortcomings. In the first one the entire activity of children, although encouraging their individuality, doesn't realize itself in cultural forms and therefore precludes children's proper acquisition of cultural tools and of socialization. In the second approach, even though activity is entirely cultural, it is absolutely deindividualized. For this reason there is a particular need not only to get children acquainted with the culture but also to give them the opportunity to meaningfully express their individuality in cultural forms.

Our task was to combine these two approaches in a way that encourages children's initiative. Our work resulted in project activity, in the frame of which children create socially significant products using culturally acceptable means. We turned to project activity in our work with gifted children because the need for socially meaningful cultural expression of their individuality was vivid and clearly presented. Project activity is not something a child does (drawing, reading, sculpting) but the process for doing so. In other words, the participating kindergartens had to rethink children's activity within the framework of the project approach (as a rule, project activity in kindergarten was presented one to two days a week). Later this technique proved to be effective for children at various levels of cognitive development. 


\section{Main features of project activity}

The first feature of project activity is that it is used only where there is a problem situation that cannot be resolved by direct action. By direct action we mean an action that is performed without a preliminary orientation to the situation and that does not require identification of resources (everything necessary for performing the action is available to the child). For example, while drawing, a child notices that the paintbrushes create a mess when lying on the table. If the child perceives this situation as a problem, she will come to the conclusion that something has to be done to keep the paintbrushes from touching the table and the clean sheets of paper lying around. In this case the child's actions enter what Vygotsky defined as a zone of proximal development: on the one hand, the experience is new to her; on the other, she won't be able to realize her intention to resolve the problem without a grown-up's help.

The second feature of project activity is that its participants must be motivat$e d$. Simple interest is not enough. It is necessary that both teacher and child bring to the project activity not only their understanding but also their personal meanings. For example, preparation for a holiday is a common event well described in many educational programs. Children may be interested in preparing for it, but the real work will begin only when teacher and children try to discover its true meaning for them. What is this holiday about? Is this a day special to a person or a country or is it a reminder of an important event? How do we celebrate this holiday? Why do we celebrate it? What are the ways of expressing our attitude toward the holiday? As soon as meanings are defined, the search for ways to present them can begin.

The third feature of project activity is the participants' subjectivity, including taking the initiative and self-manifestation. But the subjectivity of the child may manifest itself with varying degrees of intensity: a child may express an original idea (one not previously expressed in the group) or may support and slightly reshape the idea of another child. While discussing the gift options for the March 8th holiday (International Women's Day), one boy in our study decided to make his mother a card. Another boy supported this idea, saying that he could make a card for his mother and also one for his sister. From the perspective of an adult, the same idea was voiced: the creation of greeting cards. In this case, an adult might say, "We've already mentioned cards. Try to think of something else." However, it is more productive to support the initiative of the second child, emphasizing that a card for a sister was not proposed previously. Such an expression of support has several advantages: first, the adult opens new space for creative work (the adult can ask about the difference between cards for mothers and for sisters and can mention grandparents, teachers, and so forth); second, by supporting the initiative of the child, the adult gives him a positive experience of speech, and the next time he will offer his own opinion again. This is especially important for children who do not have positive social experiences of taking the initiative.

The fourth feature of project activity is its addressed nature. Because in project activity children express their attitudes and personal meanings, they always look 
for the recipient (the addressee) - the person to whom their statement in the form of a product is addressed. For this reason project activity has a pronounced social dimension and, ultimately, is one of the few socially significant activities available to preschoolers. We agree with Glăveanu (2011) that one of the signs of giftedness, creativity (expressed in the dimensions of product, process, personality, and pressure), can be fully present in all children. Project activity is built on these dimensions of creativity.

The last, but not the least, feature of project activity is exploration of the space of possibilities. Practical work with gifted preschoolers (Veraksa \& Bulicheva, 2003) showed that goal setting and planning of their own actions do not define the actual process of the movement of children's thought in search of a solution. The most valuable activity for children is to search for a way of acting that will correspond to their personal motives, will express their individuality. Because the relationship between the child's own experience and its cultural embodiment are not obvious, before moving on to planning the child explores the space of possibilities of the situation. Almost any task can be turned into a project if an adult helps a child to unlock this space, which is present in every situation. For example, to make a bird feeder in winter we must consider various aspects of the situation. What kind of birds (large or small) do we plan to feed? How can we make the feeder so that it does not overturn when a bird sits on its edge? How can we make a feeder that will not be overturned by the wind? How can we protect it from being covered with snow so that the food will stay accessible to the birds? Answers to these questions require selecting materials for making a feeder and identifying the feeder's size, shape, ways to attach it to a tree, and so forth. After a detailed discussion, when the best option is selected, actual planning begins. Now the child will have an increased understanding of every stage of making the bird feeder.

Realization of children's intentions and projects, as a rule, requires technical abilities that children lack. Therefore support from grown-ups, especially from teachers and parents, is needed. Such support allows children and grown-ups to understand each other better and establishes caring relationships between them.

The majority of preschool teachers are caring and willing to support children in their attempts to realize their goals. But it is important that in giving support teachers don't become proactive and attempt to formulate and perform creative actions for the children, including proposing options before the children think of them first.

Grown-ups, according to Vygotsky, are carriers of cultural norms, and as such they define a child's zone of proximal development. However, acting within a space defined by a grown-up doesn't make a child a subject of her own activity. Hence the task of the teacher is, on the one hand, to be led by the child in her activity and, on the other hand, to introduce the content of her activity to the culture of her kindergarten. For example, when a child completes a project, the task of the preschool teacher is to get other children and parents acquainted with the results. 


\section{Types of project activities}

We discerned three main types of projects in project activity: research, creative, and normative ones. This classification is based on an approach to the regulation of child behavior established by Venger, Diachenko, Astaskova, and Bardina (1995); Diachenko, Bulicheva (1996); and Veraksa (2011). According to this approach children perform three types of tasks in the process of development: mastering current norms (research), expressing their own views of reality (creative), and changing the current situation (normative). Each of these tasks has its own characteristics, structure, and stages of implementation.

\section{Research projects}

A typical research project is an individual endeavor, takes about a month to complete, and consists of four stages.

Stages. The first stage is the search for a problem situation. Usually the teacher carefully monitors the activities of the children, identifies areas of interest for each child, and then creates a special situation in which each child is given a research question. For example, a girl who loves to play with dolls and dress them can be directed to the question of how the dolls look, what they are wearing, and so forth. Or parents together with their children can formulate a research problem.

In the second stage children look for information that will help them to answer the research question and to realize the project. In our study we usually suggested that the children prepare with their parents a colorful album consisting of several pages. The first page contained the main research question. On the second page the importance of this question was expressed from the perspective of the children, their classmates, parents, and friends. The children conducted a survey and drew illustrations depicting the content of the replies given by their classmates, parents, friends, and themselves. The third page displayed a variety of answers to the question. Here people, books, television programs, other media were the sources of information. The children used clippings, photographs, drawings. Grown-ups assisted in producing the effect the children wanted. The next page was devoted to the expression of the children's own attitudes toward the research question. They could state an original opinion or defend the already-expressed opinion of another person. In the minds of the children different strategies for obtaining an answer were formed - turning to an adult (parent, teacher), a classmate, a book. In other words, understanding ways to transfer knowledge created a new space of possibilities. At the bottom of this page, the children described the method they used for obtaining information and justified the benefits of the chosen method. Here many of the children needed an adult's help in formulating these benefits, which were discussed with the children but not necessarily verbally - various images were used. On the last page of the album the children reflected on the possibility of using the project in real life: for example, they could tell a group of their friends about the project or they could organize a game based on the project. 
The third stage is the presentation of the projects. Children with their parents should approach the teacher about putting their presentations into the class schedule. Parents should confirm the possibility of attending this exhibition and should help their children to prepare a short summary about the work done. In the presentations, children can tell about their projects and show relevant images and notes.
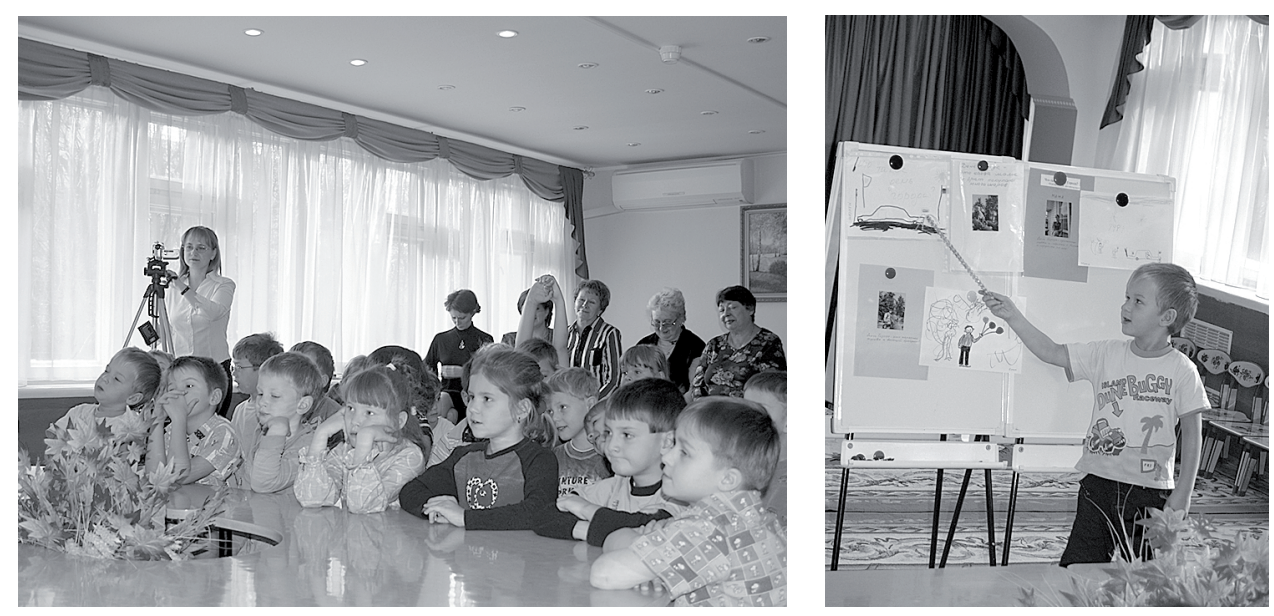

Figure 1. Presentation of the projects

The fourth stage requires the teacher to transfer the knowledge gained in playful form. At the end of the exhibition, the projects can be displayed in the kindergarten's library, stapled in a book that is easily accessible to everyone. Our experience shows that research projects not only enrich the knowledge of preschool children and stimulate their cognitive activity but also influence the content of their play.

Lessons learned from research projects. Working on research projects is interesting because children's knowledge base can be surprisingly vast, and it grows constantly as they gain new information using all the tools available. In addition, the presentation of their own projects changes their relationships with their classmates. Misha wasn't popular among the other children, who wouldn't include him in their play. As he accepted his status, he became more distant, and making contact with the other children became even harder for him. When project activity was introduced, Misha presented a project about how a car works. To complete the project, he learned not only about the major components of a car and what they do but also about major car brands and their pros and cons. After presenting his project to his classmates, in their eyes he became a car expert; he earned their respect and became very popular among the boys, with whom his communication was improved.

We were surprised to discover that project activity can help a child to cope with various situations of everyday life. Five-year-old Ayten's project, for example, was titled "Why Do Dogs Bite?" Behind this project was a problem that the girl had encountered: kind creatures living with humans and devoted to them can also harm them. 
After getting answers to her question from her parents and other grown-ups, Ayten came to the conclusion that dogs bite if they are guard dogs and are supposed to bite, or if they are being treated badly. At the end of her project, Ayten said that dogs need to be petted and treated nicely, and then they won't bite. In the photograph Ayten is petting her grandma's dog. She also taught her friend Dasha to pet dogs.

It is not necessary to purposefully search for a personal matter to be explored in a child's project. However, if a child expresses a desire to work on such a project, this initiative must be supported. A research project can be a useful tool for resolving personal questions that preoccupy children emotionally, and the value of such an experience is hard to overestimate.

\section{Creative projects}

Creative projects are usually carried out by groups of children with or without their parents. Although each of the children presents ideas for the project, only one idea is selected. This choice is not easy for children to make; they must learn not only to defend their own position but also to objectively evaluate it. In other words, they have to overcome their centration (Piaget, 1951).

Stages. In the first stage preparatory work is carried out; teachers discuss possible topics for projects that are connected with significant social situations.

The second stage is aimed at revealing children's knowledge and attitudes. For example, if the theme of a collective project is a holiday, children need to know about it, to update their own knowledge, and then to express their attitude toward the holiday, what feelings this holiday invokes. The main task is to bring children to the theme of the project and to formulate a primary task.

Teacher: Can you imagine, I went into a shop today and saw a huge crowd of people there; children and grown-ups were choosing different presents. Maybe today is somebody's birthday? What do you think?

Polya: Yes, it is because in three days it is Valentine's Day. My dad and I are also choosing a present.

Teacher: What is a holiday? What do you think a holiday is?

Agata: It is when there is fun.

Polina: It is when there are gifts.

Kolya: It is when there are sweets.

Sasha: It is when you are in high spirits.

Teacher: And who congratulates whom on that day?

Children: People in love. You congratulate the one you like, the one you love.

Ilya: And I love our kindergarten and our group.

Nikita: Let's also congratulate ourselves!

Teacher: Let's all think how to congratulate our kindergarten.

In the third stage children offer a variety of ideas for a project. The teacher needs to take notice of the most original ideas in order to repeat them to the children. The children are then encouraged to draw pictures of their ideas.

Agata: I think that any song can be put on video and later shown on TV. My grandpa did that once. I think it is pleasant for someone. 


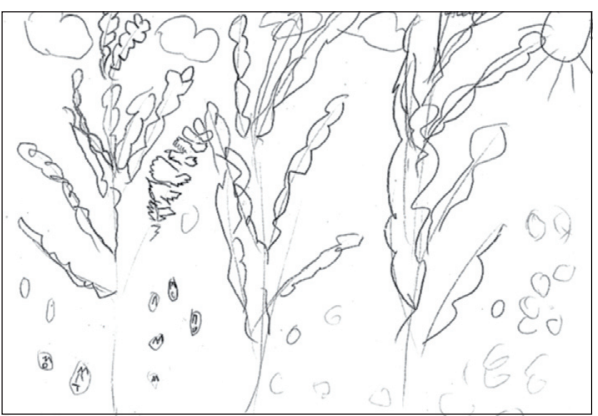

Figure 2. Alya's drawing (to draw a picture)

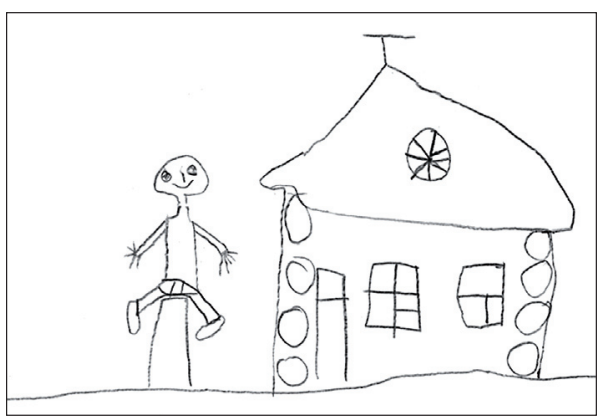

Figure 3. Kolya's drawing (to put on a play)

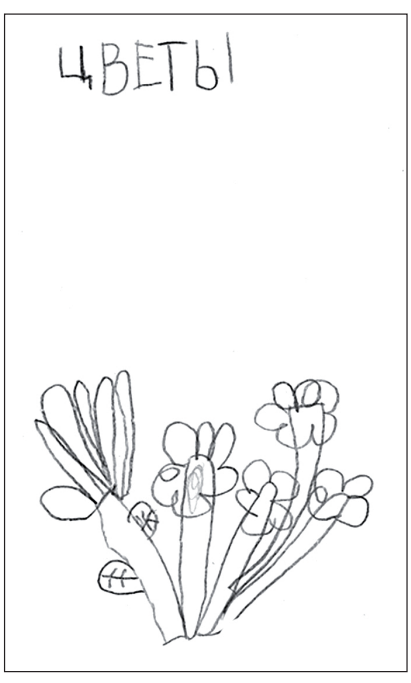

Figure 4. Nikita's drawing (to give flowers)
Seva: I think that the best thing is to give something; on this day people always give each other something. I propose that you give your favorite toys to the one you love.

Kolya: I thought of putting on a little play from some fairy tale; it's fun.

Polina: I think we can congratulate our kindergarten this way: we can bake edible valentines. Three days is enough time to bake. They can be baked out of a salty dough; they are nice to look at this way, and if they are made from edible dough, it is nice and tasty.

Olya: I would to make postcards because they can be made as valentines. I would make them for close ones, teachers and friends. In the postcard there would be a greeting and hearts.

Nikita: We could give flowers. I think that flowers are the best present.

Alya: A picture could be drawn; it is beautiful and brings joy to all.

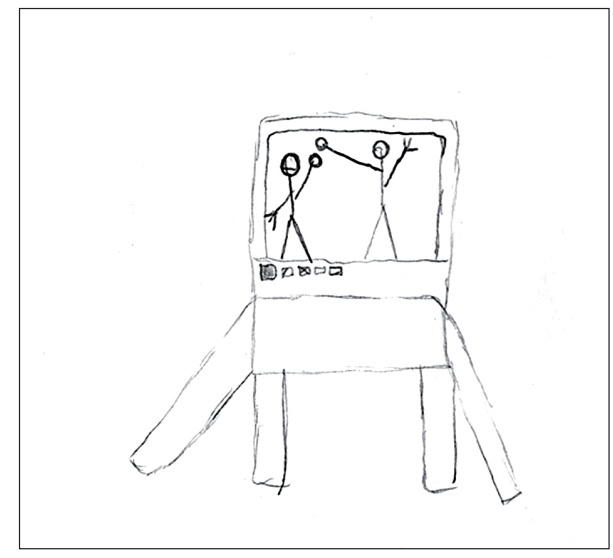

Figure 5. Agata's drawing (to shoot a video of a song and show it on TV)

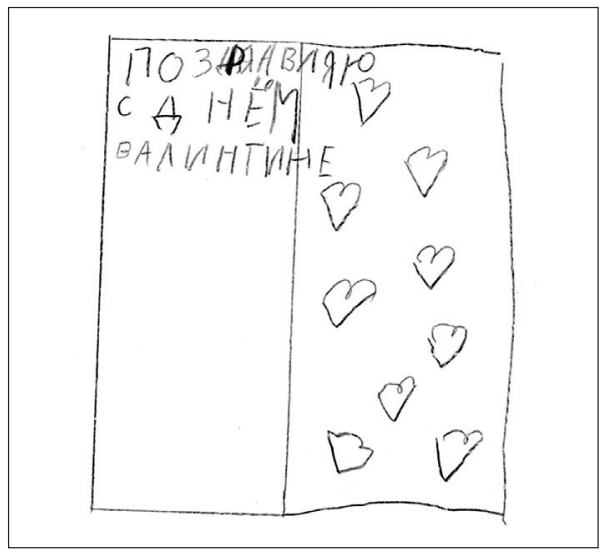

Figure 6. Olya's drawing (to make a postcard) 
In the fourth stage, children talk about their pictures and present their ideas; teachers and classmates ask questions. The task of this stage is to find a visual link between the product and the personal motives of a child. If a preschooler wants to draw a valentine for his mother, then making a valentine should be a sufficient way to express his feelings. To make a child rethink the idea, express himself in it, the teacher might ask: "Where is it seen in your valentine that you like your mother?" Or "How would your mother guess from this picture that you love her?" The important point is that meanings are always different, and every child's idea is valuable and unique; a teacher should strongly emphasize this point.

After all the ideas are presented, the children need to choose one that will be turned into a product of the creative project. Each child is given one chip; they "vote" with it by putting it on the picture that, from their point of view, expresses the most interesting idea. The teacher needs to explain that they cannot put a chip on their own drawings; they need to give it to another.

When the idea is selected, the method of its realization is discussed and plans for actions are made. Parents can participate in the project, but they should not substitute their activity for their child's.

The creative project concludes with presenting the product and receiving feedback.

Lessons learned from creative projects. Creative project activity is unique in representing and embracing a child's interests. By supporting children's projects, grownups support their unique outlook, stimulate their cognitive and creative activity, and help their cognition to develop by widening the space of possibilities through project-related peer discussions. In addition, project activity gives a child an experience of competitive interaction, which teaches that an idea has to have value to others, not only to oneself - a prerequisite for successful communication.

Through regular participation in creative project activity beginning from 5 years of age children develop the habit of using the obtained skills in different situations. For example, in one kindergarten children proposed a project aimed at organizing their winter activities; they had to decide what to build in winter on their playground and what games to play. In another kindergarten children proposed turning an empty corner of their room into a display site. They discussed what should be displayed there (schemes for upcoming projects, best drawings), created a blueprint, and agreed on constructing it.

\section{Normative projects}

A normative project is aimed at creating new rules of behavior in a given situation. Mastering the rules plays a crucial role in child development. However, most rules are presented to children as something they must learn and do. This is an area in which the child's activity may be manifested in the least degree, and often the only way of expressing oneself is to violate the rules. Implementation of a normative project allows a child to take a fresh look at a situation with a particular rule and to regard it as a space of possibilities.

A normative project has several features. First, it is always initiated by a teacher. Second, it must be based on actual problem situations related to relationships with- 
in a group of children or between adults and the children. Third, a teacher must be prepared to guarantee that a new rule developed and adopted by the children will become really effective and will govern the behavior of all participants in the situation, including the adults.

Stages. In the first stage, the children and the teacher describe a problematic situation of interaction or a violation of the rules. The children express their vision of the problem and acknowledge the fact that such a problem exists.

The second stage explores the space of possibilities of the situation. The teacher and the children offer a variety of possible behaviors (both imaginary ones and ones from their experience) and discuss the possible undesirable consequences. In tense situations, children need to present the undesirable consequences that they discovered during the discussion in drawings (symbolic form) and then show them to the group.

The third stage brings children back to group discussion, but this time the emphasis is on behavior that can help to prevent undesirable consequences. The children may offer a variety of possibilities, which are summarized by the teacher and then drawn by the children.

During the fourth stage, the children talk about their drawings and the rules of behavior that seems to them most appropriate. After seeing all the pictures, the children have to choose one general rule that they will follow in such situations and present it in the form of a sign proposed by the author of the rule. The sign should have two components: an indication of the situation and a representation of the correct way of acting in that situation.

Such work is carried out every time a new rule is needed. In this way, a book of rules is created in which children draw signs and teachers formulate and write the text of the rules. This book is in an accessible place and can be used by the children if necessary. A normative project cannot resolve all conflict situations, but the book serves as a tool for regulation of the behavior of the children. They start turning to it for advice and may add to it if necessary.

Let's consider an example of a normative project from one kindergarten. The teacher describes a problematic situation. The children are divided into two groups, and one of the groups is in a playroom; when the time comes to go to class, the children leave the game of constructing buildings unfinished. At that time the second group of children comes to the room and starts playing. When the first group returns, they discover that their buildings are destroyed or that another game is going on. This causes tears, aggression, and bewilderment. It was easy for these feelings, caused by undesirable interference in a game, to arise. Almost all the children experienced the destruction of their buildings at least once. But resolution of the problem took a much longer time. As a result of group work three signs, repeating the principle of the operation of traffic lights, were invented: a green circle near a game meant "Play what you want"; a yellow circle warned, "You can play, but you cannot change anything"; and a red circle prevented any newcomer from playing with already initiated and temporarily abandoned games. Now the regulation of relations between the two groups was in the hands of the children, who made their own decisions about whether anyone could intervene in their game and made sure that other children did not violate this rule. 
Lessons learned from normative projects. The value of normative project activity is that it resolves real conflicts and is a tangible way to support children's initiatives. A normative project allows children to work on their experience of emotionally charged situations and to create constructive ways of resolving them. This type of project allows preschoolers to gain invaluable experience in self-control, which is one of the major components of readiness for school.

\section{Results of the implementation of project activity}

\section{Teachers}

As noted by Barron et al. (1998), project activity requires simultaneous changes in curriculum, instruction, and assessment practices. The first three months of our study showed that implementation of project activity completely changes the work of preschool teachers; it modifies their interactions with colleagues and children on the basis of the teachers' increased reflection on their professional activities. A group of creative preschool teachers was formed, in which they discussed their class notes, experiences, and materials obtained by video recording. Not all the teachers were willing to accept the change: 5 of the 23 preschool teachers refused to incorporate any project activities in their work. However, 8 teachers actively introduced project activity into the everyday life of their kindergartens for 2 years. They admitted in interviews that project activity demands more time, more deliberation, active listening, and a desire to help children express themselves and take the initiative. Despite the frequent need for after-hours work, those teachers managed to get their colleagues from the neighboring kindergartens interested in project activity.

\section{Parents}

As we mentioned before, the successful realization of children's projects is impossible without the support of their parents. The degree of parental involvement, based on our experience, depends not so much on the activity of the preschool as on the activity of the children. Parents were excited to notice their children's new initiatives at home: the children started to come up with ideas about what to do together at home, often involving neighbors and other people, and they became more inquisitive and overall more interesting to their parents. Teachers began to hear increasingly in parental meetings the phrases "I didn't know my child is so bright" and "I had no idea that this interests my child." We have seen that parents' participation in the project activity of their children makes little victories over the routine of their everyday life happen.

\section{Children}

As we noted, we used project activity to work with gifted children. They were selected on the basis of recommendations for the identification of intellectually gifted children of preschool age (Diachenko et al., 1996). These recommendations establish criteria for selecting gifted children based on the results of a se- 
ries of tests. Also, children with a normal level of cognitive development were enrolled in the groups along with the gifted. Ultimately 2 groups were formed, each including gifted children ( 9 and 10 children, respectively) and children with a normal level of cognitive development (16 and 15 children, respectively). The experimental group differed from the control group in one respect: $50 \%$ of its class time was devoted to project activity. Project activity was completely absent in the control group.

The experiment lasted for the 2 years before the children started school. There were clear differences between the nature of participation in project activities for gifted children and children with normal levels of development: the gifted children were more active and participated more in group projects. At the end of the second year results obtained from the same tests (Diachenko et al., 1996) showed that children from the experimental group performed better than children from the control group (Veraksa \& Bulicheva, 2003). The indicators of cognitive development for the gifted children within the experimental group changed only slightly, but the indicators for the children with normal levels of cognitive development in the experimental group improved significantly compared with the results for those in the control group. The experimental results allowed us to assert that project activity can be an effective technique for working not only with intellectually gifted preschool children but also with normally developing preschool children.

The children in both the experimental and the control groups graduated from kindergarten and were enrolled in different schools. Habok (2015) notes that children who experience learning through project activity tend to show interest in learning after the projects are over. We wanted to find out how those children's participation in project activity in kindergarten affected their academic performance in school. Would they be able to save and develop their individuality in a new situation? In 2012, 12 children from the experimental group and none of the children from the control group passed all their final school exams with excellence. We believe that these numbers speak for themselves.

\section{Conclusion}

Project activity is extremely popular worldwide and is actively used by practitioners in the field of preschool education. Historically in Russia the idea of project activity became known through the work of J. Dewey (1916/2009) and W. Kilpatrick (1918). The core of the technique was the independent action of children in the process of learning. A key achievement of the children was the ability to plan their own actions and to obtain the planned result. Beginning from Vygotsky's (1978) cultural-historical theory and Venger's (1988) understanding of giftedness, we turned to this technique as a cultural way of implementing activity for intellectually gifted children. However, in our work we found that for the gifted child exploring the space of possibilities (which is not described in the standard project-activity approach) not only is of great interest but is of great value. Furthermore, the results of the first experiment have shown the effectiveness of our modification in work with normally developing children. 
We believe that the proposed modification of the project-activity technique promotes understanding of the subjectivity of the child: if in the traditional version of project activity children were considered to possess subjectivity because they could do projects by themselves, now they have to accomplish another task to possess subjectivity: they have to do projects that express their own feelings and their attitude toward the world. Exploration of a situation's space of possibilities is not simply absorption of proposed adult content; it makes the child see the design of the content and the history of its formation. Experience with project activity gradually leads children to understand that they are capable of making their own contributions to cultural content and of improving or changing it.

\section{Acknowledgments}

We would like to express gratitude to Professor Ingrid Pramling Samuelsson and Professor Bert van Oers for their valuable comments on this article.

\section{References}

Barron, B.J.S., Schwartz, D. L., Vye, N. J., Moore, V. A., Petrosino, A., Zech, L., \& Bransford, J. (1998). Doing with understanding: Lessons from research on problem- and project-based learning. Journal of the Learning Sciences, 7, 271-311.

Dewey, J. (2009). Democracy and education: An introduction to the philosophy of education. New York: WLC Books. (Original work published 1916)

Diachenko, O., \& Bulicheva A. I. (1996). Rekomendatsii po viyavleniyu umstvenno odarennyh detey doshkolnogo vozrasta [Recommendations for diagnostics of preschool intellectual giftedness]. Moscow: Russian Academy of Education.

Glăveanu, V. (2011). Children and creativity: A most (un)likely pair? Thinking Skills and Creativity, 6, 122-131.

Grzegorzewska, K., \& Konieczna-Blicharz, J. (2011). The Lights Pre-project: Implementation of the project approach with children under 3 years of age. Early Childhood Research and Practice, 13, 1.

Habok, A. (2015). Implementation of a project-based concept mapping developmental programme to facilitate children's experiential reasoning and comprehension of relations. European Early Childhood Education Research Journal, 1, 129-142. doi: 10.1080/1350293X.2014.991100

Katz, L. G., \& Chard S. C. (2000). Engaging children's minds - the project approach. Stanford, CT: Ablex.

Kilpatrick, W. H. (1918). The project method. Teachers College Record, 19, 319-335.

Kogan, Y., \& Pin, J. (2009). Beginning the journey: The project approach with toddlers. Early Childhood Research and Practice, 11, 1.

Leontiev, A. N. (2000). Lekcii po obshchey psykhologii [Lectures on general psychology]. Moscow: Smysl.

Piaget, J. (1951). The psychology of intelligence. London: Routledge.

Venger, L. A. (1988). The origin and development of cognitive abilities in preschool children. International Journal of Behavioral Development, 11(2), 147-153. doi: 10.1177/016502548801100201

Venger, L.A., Diachenko, O., Astaskova, N.F., \& Bardina, R.I. (1995). Obrazovatelnaya programma "Odarenniy rebenok" [Educational program "Gifted Child"]. Moscow: Gnom. 
Veraksa, N. (2011). Development of cognitive capacities in preschool age. International Journal of Early Years Education, 1, 79-88. doi: 10.1080/09669760.2011.571003

Veraksa, N., \& Bulicheva, A. (2003). Razvitiye intellektualnoy odarennosti v doshkolnom vozraste [Development of intellectual giftedness in preschool age]. Voprosi Psihologii [Issues in psychology], 6, 17-31.

Vygotsky, L. (1978). Mind in society: The development of higher psychological processes. M. Cole, V. John-Steiner, S. Scribner, \& E. Souberman (Eds.). Cambridge, MA: Harvard University Press. (Original works published 1930-1934)

Original manuscript received April 05, 2015 Revised manuscript accepted June 01, 2015 First published online June 30, 2015 